\title{
The Effect of Spiritual Motivation and Compensation on The Employee Performance of The Bank of Center Sharia Jabar Banten
}

\author{
Laili Rahmawati \\ STEBI Al Jabar Bandung \\ E-mail: lailirahmawati8022@gmail.com
}

\begin{abstract}
Nowadays, the sharia banking industries in Indonesia have increased dramatically because there are many the companies of conventional banking that have redeveloped to be a the sharia banking. According to many, the industries of sharia banking require the systems that can spur them to be a large banking company not only in Indonesia but also in the world. Meanwhile, the sources that they have both of human and natural resources respectively need the increasing to compete in this era. Moreover, to enhance the capacity of employees are indispensable work to create the greate employee and this is quite essential for the sharia banking companies. The aim of this study is to provide a describing regarding the impact of spiritual motivation and compensation on the employee performance. The methodology that be used in this research is a survey method with explanatory likewise the spiritual motivation and the compensation are independent variable meanwhile employee performance is dependent variable. In addition, the location of the survey is in the Bank of Center Sharia Jabar Banten. The result of the study has delivered that both of the spiritual motivation and the compensation have the significant positive impact to incline the employee performance of the Bank of Center Sharia Jabar Banten.
\end{abstract}

Keywords. Sharia Banking, Spiritual Motivation, Compensation and Employee Performance.

\section{INTRODUCTION}

The competition in the era of globalization is increasingly tighter, human resource management is very important and must be considered by company leaders to maintain the company's existence. In order to be able to maintain the success and survival of the company, a leader must always maintain and increase the resources he has including increasing spiritual motivation and compensation in improving employee performance. As with scarcity (under supply), an inseparable state of the employee itself, short-term insensitivity to hisdemands, having an attitude in determining wages, is the same thing in all economic systems. Employees are company assets and are recognized production factors in every economic system. Employee Specificity.

The development of Islamic banking in the reform era was marked by the passage of Law No.10 Year! 998 and in this law is regulated in detail the legal basis and types of uaaha that can be operated and implemented by Islamic banks. The law also provides direction for conventional banks to open sharia branches or even convert themselves totally into sharia banks (Antonio, 2002).

The opportunity was apparently welcomed enthusiastically by the banking community. A number of banks have begun to provide training in the field of sharia charges for their staff. Some of these banks want to sell to open sharia divisions or branches in their institutions. Some even plan to convert themselves completely into Islamic banks. Bank Indonesia has anticipated this from all sections, especially those directly related to institutions such as the DPNP (Directorate of Banking Research and Regulation), credit, supervision, accounting, research and monetary (Bank Indonesia, 1999).

The development of the BJB Sharia bank within 4 years, the bjb syariah bank has developed a network of branch office services in the West Java, DKI and Banten regions. In its development after the spin off of the bjb sharia bank service office which initially only consisted of 1 head office, 6 
branch offices and 15 sub-branch offices, now along with the growth that occurred the number of branch offices and sub-branch offices increased to 8 branch offices and 56 branch offices maid plus 4 outlets.

Table 1.1

BJB Sharia Bank

\begin{tabular}{|l|c|c|c|}
\hline Network Network & $\mathbf{0 1 2}$ & $\mathbf{0 1 3}$ & $\mathbf{0 1 4}$ \\
\hline Branch Offices & 5 & & \\
\hline Sub-Branch Offices & 6 & 1 & 5 \\
\hline Cash Offices & 1 & & \\
\hline Outlet & 3 & & \\
\hline
\end{tabular}

Souce: (Bank Indonesia, 1999)

The importance of quality human resources or human resources who have high spiritual motivation in organizing, in this works especially in Islamic financial institutions which require more competence in understanding and implementing spiritual motivation as reflected in daily work activities. However, it is not uncommon for HR taken by Islamic financial institutions to come from conventional institutions in this study, from Bank Jabar Banten, which was placed in the BJBS bank which was originally a sharia business unit from a conventional BJB bank. Over time, Bank Jabar Banten Syariah could eventually become a BUS, but there are still many BJBS employees who come from conventional BJB (Adam, 2012).

Compensation that is the employee's right to work must be highly considered by the bank, giving compensation will certainly go well if the company runs smoothly. Compensation provided by companies can be in the form of financial compensation and non-financial compensation. Financial compensation in the form of salaries, commissions, bonuses, while financial compensation can be in the form of training, tiered training, periodic training and others that support employee performance (Notoatmodjo, 2009).

From this background, it is deemed necessary to conduct research on the influence of spiritual motivation and compensation on the performance of employees of PT. Bank Jabar Banten Syari'ah.

\section{LITERATURE REVIEW THEORETICAL FOUNDATION The Spiritual Motivation}

Concept of metamotivation developed by Abraham Maslow, which divides motivation into two scopes namely material motivation and spiritual motivation in Zohar and Marshall. These authors assert that the greater role of religion plays in one's identity, where it becomes increasingly difficult for other factors to thwart the influence of the role of religion in life. Theconcept of spiritual motivation according to Umar Chapra is in line with what Weber put forward that the developing Western world is not driven by consumer values, but rather by the motivation of creative values called the work ethic (Meldona, 2009).

Research on spiritual intelligence has been carried out among them by Howard in 2002. According to Howard, spiritual can be interpreted as an invisible force, containing all the good experiences of experiences with others, one's own experience, experiences related to all life. Spirit gives strength to humans, spirit helps someone to show the truth, reality for themselves and the organization.

\section{Compensation}

Compensation is anything that is received by employees as a remuneration for their work or service. Compensation is a matter that is received by an employee, whether in the form of money or not money as a remuneration given for employee efforts (employee contributions) that he provides to the organization (Sirait, 2006).

According to Mangkuprawita, quoted by Meldona, explained that "compensation includes a form of direct cash payments, indirect payments in the form of benefits achieve higher productivity."

According to Sirait, "Compensation is a matter that is received by employees, whether in the form of money or not money in return for services provided to the organization." According to Tulus, 
"Compensation or compensation is defined as givingdirect,rewards financial and non-financial fair andthat are fair and appropriate to employees for their contribution in achieving organizational goals" (Tulus, 1995).

\section{Performance}

Performance is the extent to which a person has played a part in implementing an organization's strategy, both in achieving specific objectives related to the role of individuals and or by showing competencies that are declared relevant to the organization (Darmawan, 2011).

Gibson in Gorda states that employee performance is a measure that can be used to determine the comparison of the results of the implementation of tasks, responsibilities given by the organization in a certain period and can be relatively used to measure work performance or organizational performance. Performance is a result of work achieved by a person in carrying out the tasks assigned to him based on skill, experience and seriousness of time measured by considering the quantity, quality and timeliness according to the State Mangku. Performance is an embodiment of work performed by the employee or organization concerned (Lemita, 2011). Performance can be measured through certain measurements (standards) where quality is related to the quality of work produced, while quantity is the amount of work produced in a certain period of time, and timeliness is the suitability of the planned time. Performance is a function of motivation and ability, to complete a task or work someone must have a degree of willingness and a certain level of willingness, willingness and skill someone is not effective enough to do something without a clear understanding of what will be done and how to do it (Puspanegara, 2003).

\section{PREVIOUS RESEARCH}

(Puspanegara (2003) in the thesis research of the postgraduate graduate management master's program in economics at the University of Lampung, entitled "The Effect of Motivation, Compensation, and Capability on the Performance of Civil Servants (PNS) in the Department of Agriculture, Animal Husbandry and Fisheries in North Lampung Regency" . This research was conducted to determine the effect of motivation, compensation, and ability on the performance of civil servants in the North Lampung District Office of Agriculture, Agriculture and Fisheries. The analysis technique used is quantitative descriptive analysis, while testing hypotheses using multiple regression analysis.

The effect of compensation in terms of quality human resources that have been studied by Agustinus Ady Chandra under the title compensation effects in terms of quality human resource management in the world of tourism. Second, the effect of giving compensation to the increase in work productivity studied by Eddi Widodo and also research conducted by Tauf Tristianto. Third, the effect of compensation on employee work in consumer recruitment examined by Asmaul Fauziah with the title effect of compensation on employee work in the recruitment of pilgrims.

Fourth, namely research in the form of a thesis about the effect of compensation and organizational climate on improving employee performance researched by Wenny Soliany Permatasari, and also research by Lemita with the title analysis of the effect of compensation on employee satisfaction and performance.

Andina Widya Harsanthy's thesis entitled the effect of motivation on the performance of employees of the Integrated Licensing Board (BPT) of Sragen Regency, Sebelas Maret University, Surakarta, 2011. With the test results that intrinsic and extrinsic work motivation affects the performance of Sragen BPT employees (Lemita, 2011).

\section{RESEARCH METHODOLOGY}

The research method used is after conducting a preliminary study and then related to the formulation of the problem to be investigated by using a survey method with extensive research methods, but only certain aspects will be discussed. This research belongs to explanatory research (explanatory research). Thus, because this study links 3 (three) variables, namely spiritual motivation as an(with anindependent variableindependent variable $\mathrm{X}_{1}$ ) and compensation as an(with anindependent variableindependent variable, with a statistical notation $\mathrm{X}_{2}$ ), while employee performance is a variable bound (dependent 
variable, with statistical Y notation). In this study, it will use a questionnaire as a medium to obtain primary data in the form of employee's spiritual motivation and compensation and employee performance at the BJB Syariah Center (Gujarati, D, 2003).

The sampling technique used is Proportionate Stratified Random Sampling, which is sampling from members of the population randomly and proportionally. This method is used because the population is heterogeneous, although the level of education is not distinguished, the length of work, income and so on, in this study the employees of the central Islamic BJB bank (Singaribuan, 1998).

This research was conducted at Bank Jabar Banten Sharia Center because training policies and matters related to improving employee performance with spiritual motivation programs and compensation policies are part of the human resource division program. The Central BJB Syariah Office is located at Jalan Braga No. 135 Bandung with telephone number 022-4202599 and fax number. 022-4202550.

The type of data in this study will be divided into two parts, namely qualitative data and quantitative data. Qualitative data sourced from analysis of preliminary study results and interviews. While quantitative data is data in the form of numbers obtained from the distribution of closed questionnaires, namely questionnaires that have provided answers so that respondents just choose. This questionnaire was given to a sample of employees who were in the BJB Syariah on the variables studied, namely spiritual motivation as a variable $\mathrm{X}_{1}$, compensation as a variable $\mathrm{X}_{2}$ and performance as a variable $\mathrm{Y}$.

The data source of this study were employees in the BJB Syariah environment, the population of The number of employees is 190 people, in this case the sample used is the quota sampling because it bases itself on the number that has been determined and focused on the sample. To maximize this study the sample taken amounted to 50 employees, consisting of employees in the BJB Syariah central office environment.

If a large number of subjects can be taken between $10 \%-15 \%$ or $20 \%-25 \%$ or more, depending at least from:

a. The ability of the researcher is seen in terms of time, energy and funds.

b. Narrow breadth of the area of observation of each subject, because this involves a lot of data at least.

The size of the risk borne by researchers. For studies with large risks, of course if the sample is large, the results will be better.

\section{RESULTS AND DISCUSSION}

\section{The Effect of Spiritual BJBS Employee Performance}

Motivation oninfluence of spiritual motivation on employee performance at BJBS headquarters has a significant positive effect. The partial hypothesis test results show that the spiritual motivation variable $\left(\mathrm{X}_{1}\right)$ has at value calculated $(2.153)>$ tvalue table $(2.021)$, then the decision is to accept $\mathrm{H}_{\mathrm{a}}$ and $\mathrm{H}_{\mathrm{o}}$ rejected. This means that the variable of spiritual motivation has a significant effect on the performance of employees at BJB Syariah head office. The influence of spiritual motivation on employee performance is relevant to the teachings of Islam, where Allah SWT calls on His servants to be religious (or Muslim) as a whole (QS Al-Baqarah: 208). Every Muslim, both in thinking, acting and acting, is ordered to convert to Islam. In carrying out economic activities, social, political, or any activity including working a Muslim is ordered to do so in order to worship Allah. In line with Stephen R Covey, in his book First Thing First (1994) the highest need for actualization is no longer selfactualization, but there is still a higher need for self-transdence or spiritual needs.

This research is also in line with what Awidler stated in Arapula (1997) the demand for spiritual needs is so urgent for universal humanity that even in the simplest problems it must be pursued in the path of spirituality. In the image of the Eastern view, all forms of manifestation of the power of human creation start from the point of transcendental needs that are so evident in ethics. In the west the 
transcendental aspect begins with conceptual study, then in the east, the transcendental nature is united in every social behavior and teachings, including harmony with nature. All principles of life are based on transcendent meaning. About efforts to awaken transcendental meaning in life are examined by Dorff, Sadler, Thottungal in Ash'arie.

The influence of spiritual motivation on employee performance is relevant to the teachings of Islam, where Allah SWT calls on His servants to be religious (or Muslim) as a whole (QS Al-Baqarah: 208). Every Muslim, both in thinking, acting and acting, is ordered to convert to Islam. In carrying out economic activities, social, political, or any activity including working a Muslim is ordered to do it in the context of worshiping Allah (Ancok, 1994).

In accordance with the guidance of Islamic faith, the performance in Islamic economic motives is to seek "luck" in the world and in the hereafter as khalifatullah with the way of worship in a broad sense. Every Muslim must be aware that all gods (God) who will distract attention (tawajuh) to Allah, are unpardonable polytheistic sins which then bring awareness that the soul, heart, mind and the entire system of attitudes and behavior must remain on the linear line towards and departing from the awareness of monotheism (aqidah) solely. So that in general, the aqeedah of every Muslim can be used as one of the variables of spiritual motivation to improve employee performance (Zadjuli, 1999).

Spiritual motivation with the aqeedah variable has the earliest influence on employee performance, which will give the spirit (spirit) on the next motivation, then influence on worship behavior and muamalah behavior. The influence of spiritual motivation on employee performance when tested and analyzed turned out to be significantly positive, meaning that the practice / behavior of employees' spiritual motivation is in accordance with the teachings of Islam.

\section{Effect of Compensation on Employee Performance The}

The effect of compensation on employee performance at BJBS headquarters has a significant positive effect. The partial hypothesis test results show that the compensation variable $\left(\mathrm{X}_{2}\right)$ has avalue $_{\text {calculated }}(2.687)>$ tvalue $e_{\text {table }}(2.021)$, then the decision is to accept $\mathrm{H}_{\mathrm{a}}$ and $\mathrm{H}_{\mathrm{o}}$ rejected. This means that the compensation variable has a significant effect on the performance of employees at BJB Syariah head office.

This research is in line with the theory put forward by Muhammad Ismail Yusanto and Muhammad Karebet Widyayakusuma, that in organizations the compensation problem is a very complex matter, but it becomes a very important thing for the organization itself. Providing compensation to employees must have a logical and rational basis. However, emotional and humanitarian factors must not be ignored. The personnel department usually designs and administers employee compensation. If compensation is given correctly, employees will be more satisfied and motivated to achieve organizational goals. Compensation is also an important factor that influences how and why people choose to work in one organization rather than another (Handoko, 2001).

In organizations the problem of compensation is a very complex thing, but it becomes a very important thing for the organization itself. Providing compensation to employees must have a logical and rational basis. However, emotional and humanitarian factors must not be ignored. The personnel department usually designs and administers employee compensation. If compensation is given correctly, employees will be more satisfied and motivated to achieve organizational goals. Compensation is also an important factor that influences how and why people choose to work in one organization rather than another (Jackson, 2006).

Employees not only need rewards or compensation in the form of money, but more than that. Compensation includes all expenses incurred by the company both material and non material. Financial compensation includes basic salary, benefits, bonuses, and overtime. The basic salary is adjusted to the grade of each employee. where the higher the grade of the employee means the greater responsibility assumed. Therefore, the amount of the basic salary of each employee is different according to gradestheir respective (Wibisono, 2002).

\section{The influence of spiritual motivation and compensation on employee performance}

The influence of spiritual motivation and compensation simultaneously on employee performance at BJBS headquarters has a significant positive effect. This is evidenced by theF value $_{\text {calculated }}$ of 7.125 , using aconfidence interval of $95 \%$ or $\mathrm{a}=0.05$, then from the $\mathrm{F}$ distribution table a value of 3.19 is obtained. By comparing the value of $F_{\text {arithmetic }}$ with $F_{\text {table, }}$, then $F_{\text {arithmetic }}(7.125)>F_{\text {table }}$ 
(3.19). The decision was $\mathrm{H}_{\mathrm{o}}$ rejected and $\mathrm{H}_{\mathrm{a}}$ accepted, meaning that simultaneous spiritual motivation and compensation variables affect significantly (highsignificant)the performance of employees in BJB Syariah headquarters. The results are consistent with the theory presented by Zadjuli states that Islam has a performance assessment of its own that includes some of the following elements:
a. Intention operation is due to
b. Allah,in work have to enforce the rules of the totality of
c. motivation is to seek their fortune in the world and in the hereafter preservation of the natural environment.
e. Maintaining a balance between looking for wealth and worship
f. After succeeding in working should be grateful to Allah SWT.

d. In the work required application of the principle efficiency and benefits while maintaining the

\section{CONCLUSION}

The difference in motivation between the West and Islam is that Islam besides providing material and financial incentives, also uses spiritual motivation. The effectiveness of these spiritual incentives is proven to be stronger than the material ones. this happens because Islam always touches the hearts of every Muslim and encourages him to maintain his Islamic consciousness. According to Ancok, the variable of spiritual motivation has been believed by Islamic scholars and people who study psychology believe more effectively than others. But this does not mean completely eliminating material and financial motivation in humans.

For Sharia BJB Bank the head office is expected to continue to improve and enhance the application of a good system in improving employee performance through daily, monthly or annual activities relating to the spiritual motivation of employees, both in terms of aqeedah, worship and muamalah that can be applied daily in the Islamic work ethic. And no less important in terms of compensation both financial and non-financial which must continue to be assessed the level of eligibility and standardization, because from the study found respondents who were still not satisfied with the compensation policy given to employees of the Central BJBS Bank. Maybe this is influenced by several factors, both external and internal that still need to be studied in more depth.

For Academic, it is expected that there will be more research in spiritual motivation and compensation research related to employee performance, because in this study it shows that the coefficient of determination (R Square) of 0.233 or $23.3 \%$, this means that the dependent variable is employee performance $(\mathrm{Y})$ can be explained by the independent variables of spiritual motivation $\left(\mathrm{X}_{1}\right)$, and compensation $\left(\mathrm{X}_{2}\right)$ of $23.3 \%$, while the remaining $76.7 \%$ is explained by other variables. Other variables that affect the performance of employees by $76.7 \%$ need further research.

\section{REFERENCE}

Adam, L. O. B. (2012). The Role of Religious Spiritual Motivation on Organizational Citizenship Behavior (OCB) and Lecturer Performance (Study of Lecturers at Haluoleo University, Kendari). Management Application Journal, 10(4).

Ancok. (1994). Islamic Psychology. Yogyakarta: Student Library.

Antonio, M. S. (2002). Sharia Bank From Theory To Practice. Gema Insani Press.

Arapula. (1997). in Asy'arie. Asy'arie, p. 33.

Bank Indonesia. (1999). Instructions for Opening of Sharia Bank Offices. p. 142.

Darmawan, I. M. Y. (2011). The effect of Non-Physical Motivation and Work Environment on Discipline and Performance of Employees of the Nikki Hotel Denpasar. Denpasar: Udayana University. 
Gujarati, D, S. Z. (2003). InterpretationBasic Ecometry. Jakarta: Erlangga.

Handoko, T. H. (2001). Personnel Management and Human Resources. Yogyakarta: BPFE.

Jackson, R. L. M. and J. H. (2006). Human Resources Management. Jakarta: Salemba Empat.

Lemita, A. (2011). Analysis of the Effect of Compensation on Employee Satisfaction and Performance of the Production Section of PT. PGW Chemicals. In Master of Business Management Thesis. Bogor: Bogor Agricultural Institute.

Meldona. (2009). Human Resource Management. Malang: UIN Malang Press.

Notoatmodjo, S. (2009). Human Resources Development. Jakarta: PT. Rineka Cipta.

Puspanegara. (2003). The effect of Motivation, Compensation, and Capability on the Performance of Civil Servants (PNS) in the North Lampung Regency Agriculture, Animal Husbandry and Fisheries Office. In Thesis Masters in Management Economics. Lampung: Lampung University.

Singaribuan, M. and E. (1998). Survey Research Methods (11th ed.). Jakarta: Rineka Cipta.

Sirait, J. T. (2006). Understanding Aspects of Human Resource Management in Organizations. Jakarta: PT. Gramedia Widiasarana Indonesia.

Tulus, M. A. (1995). Human Resources Management. Jakarta: PT. Gramedia Pustaka Utama.

Wibisono, C. (2002). The Effect of Spiritual Motivation on Performance: Employees of the Manufacturing Industry Sub Sector in Batamindo Batam. Surabaya.

Zadjuli. (1999). Shaping Humans into Caliphs on Madaniyah Earth. Surabaya: Center for Alternative Policy Studies. 